\title{
ZALEŻNOŚĆ KONTYNGENCJI CZASU I KOSZTU W HARMONOGRAMACH BUDOWLANYCH
}

\begin{abstract}
Streszczenie: Uwzględnianie buforów czasu i/lub kosztu w strukturze harmonogramów jest coraz popularniejszą metodą zabezpieczania harmonogramów budowlanych przed wpływem wielu czynników ryzyka występujących podczas realizacji tych obiektów. Spotykane dotychczas w literaturze rozwiązania najczęściej pozwalają wyznaczyć ich wielkość niezależnie jedne od drugich. Oznacza to, że wielkość buforów kosztu nie uwzględnia nakładów, jakie należy ponieść na skrócenie zadań, które to są podstawowym założeniem metody Goldratta. W artykule wskazano, że kontyngencja kosztów zgromadzona w buforach powinna być uzależniona od rozmiarów skrócenia zadań, które dany bufor chroni. Zdefiniowano założenia proponowanej metody wyznaczania wielkości buforów kosztu w zależności od przyjętego terminu zakończenia całego przedsięwzięcia i wynikających z tego skróceń czasu zadań oraz opisano sposób prowadzenia obliczeń. Zaproponowana metoda wyznaczania buforów została zilustrowana i zweryfikowana na przykładzie dużego harmonogramu przebudowy zbiornika wodnego.
\end{abstract}

Słowa kluczowe: kontyngencja czasu, kontyngencja kosztu, analiza ryzyka, bufor czasu, bufor kosztu, harmonogram budowlany

\section{Wprowadzenie}

Uwzględnianie buforów czasu i/lub kosztu w strukturze harmonogramów jest coraz popularniejszą metodą zabezpieczania harmonogramów budowlanych przed wpływem wielu czynników ryzyka występujących podczas realizacji tych obiektów $[3,6,8]$. W literaturze można spotkać szereg różnych propozycji wyznaczania lokalizacji, ilości i wielkości różnego rodzaju buforów w zależności od przyjętych założeń i danych, którymi dysponujemy do wykonania niezbędnych obliczeń. O ile potrzeba wyznaczania kontyngencji czasu jest raczej bezsporna, o tyle dyskusyjna jest możliwość gromadzenia zapasowych zasobów niezbędnych w realizacji każdego przedsięwzięcia budowlanego. Co prawda E. Goldratt wspomina w swojej książce również bufory zasobów [2], jednak ze względu na szeroki wachlarz zasobów odnawialnych i nieodnawialnych używanych w proce-

\footnotetext{
${ }^{1}$ Mieczysław Połoński, Katedra Geoinżynierii, Wydział Budownictwa i Inżynierii Środowiska SGGW, ul. Nowoursynowska 159, 02-776 Warszawa, e-mail: mieczyslaw_polonski@sggw.pl
} 
sie budowlanym, praktyczne wyznaczenie parametrów takich buforów jest bardzo trudne. Trudna i kosztowna wydaje się również techniczna strona utrzymania w gotowości takich zasobów, zwłaszcza w odniesieniu do zasobów odnawialnych. Wspomniane trudności z kontyngencją zasobów skłoniły wielu badaczy do wniosku, że drugim elementem, którego kontyngencję powinno się brać pod uwagę są środki finansowe [1,5]. W literaturze można spotkać metody wyznaczania rezerwowych wielkości kosztów lokowanych w buforach, jednak zazwyczaj parametry buforów czasu i buforów kosztu wyznaczane są niezależnie jedne od drugich. A przecież od dawna rozpoznane jest istnienie związku pomiędzy czasem realizacji każdego zadania i całego przedsięwzięcia budowlanego i kosztem ich realizacji. Skoro stworzenie buforów czasu łączy się najczęściej ze skróceniem wstępnie planowanych czasów poszczególnych zadań, a koszt wykonania zadań w harmonogramie zależy od ich czasu, wielkości buforów kosztu chroniące te zadania powinny również zależeć od przyjętych czasów zadań.

W artykule wskazano na konieczność uzależnienia kontyngencji kosztu od terminu realizacji harmonogramu i wielkości skrócenia wstępnie planowanych czasów zadań. Podano najważniejsze założenia proponowanego rozwiązania, a opisany sposób wyznaczania buforów czasu i kosztu został zilustrowany i zweryfikowany na przykładzie dużego harmonogramu przebudowy zbiornika wodnego.

\section{Założenia proponowanej metody}

Zaproponowany w artykule sposób wyznaczania współzależnych wielkości kontyngencji czasu i kosztów oparty jest na następujących założeniach:

- podstawą wyznaczenia wartości kontyngencji czasu i kosztu jest harmonogram sieciowy przedsięwzięcia ze zdefiniowanymi, wyjściowymi czasami i kosztami wszystkich zadań,

- kontyngencja czasu i kosztu wyznaczana jest dla wspólnych buforów zlokalizowanych w strukturze sieci zależności harmonogramu,

- skrócenie czasu zadań częściowo chronione jest rezerwą czasu zgromadzoną w buforach, a częściowo służy przyspieszeniu realizacji przedsięwzięcia,

- skrócenie czasu każdego zadania poniżej czasu wyjściowego generuje dodatkowy koszt, zależny od wielkości skrócenia,

- koszt skrócenia zadań częściowo zostanie przypisany bezpośrednio do skracanych zadań, a częściowo do chroniących ich buforów,

- maksymalne skrócenie każdego zadania uwarunkowane jest możliwościami technologicznymi i organizacyjnymi analizowanego przedsięwzięcia,

- obliczane koszty przedsięwzięcia powinny obejmować zarówno koszty bezpośrednie zadań, jak i koszty pośrednie dla całego przedsięwzięcia,

- na wielkość buforów kosztu składają się dwa składniki: zabezpieczenie kosztów wykonania zadań wyjściowych (bez skrócenia) i kontyngencja kosztów wynikająca z założonego skrócenia czasu zadania i związanych z tym kosztów. 


\section{Przykład obliczeniowy}

Sposób obliczenia wielkości buforów czasu i kosztów na podstawie zaproponowanych założeń zostanie przedstawiony na przykładzie jednopunktowego harmonogramu przebudowy zbiornika małej retencji w Małomicach wraz z infrastrukturą towarzyszącą [7].

Ponieważ cały szczegółowy harmonogram liczył 298 zadań, w artykule przestawiono jego bardzo uproszczoną wersję, zachowując jednak podstawowe etapy robót i ich powiązania. Struktura uproszczonego harmonogramu powstała na podstawie struktury SPP harmonogramu szczegółowego, a czasy i koszty poszczególnych skomasowanych zadań zostały wyznaczone jako czasy i koszty poszczególnych zadań sumarycznych w pierwotnym harmonogramie. Dzięki temu zachowano przebieg ścieżki krytycznej i podstawowe parametry harmonogramu wyjściowego: wstępny czas realizacji 264 dni robocze i koszt 8935177 zł kosztów bezpośrednich i 1244760 zł kosztów pośrednich tzn. całkowity koszt wykonania obiektu to 10179937 zł. Zarówno harmonogram uproszczony jak i szczegółowy sporządzony był w programie MS Project. Na rysunku 1 przedstawiono schemat sieci zależności i przebieg ścieżki krytycznej (pogrubione ramki) harmonogramu uproszczonego.

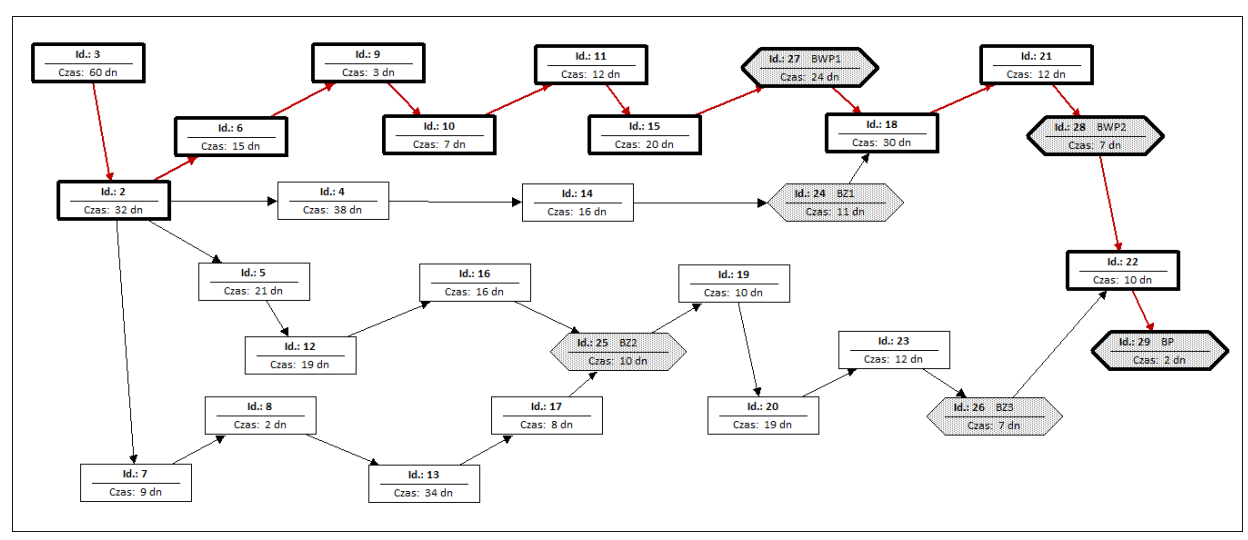

Rys.1. Schemat sieci zależności i przebieg ścieżki krytycznej (pogrubione ramki) harmonogramu z wstawionymi buforami czasu i kosztu

Fig. 1. The relationship network with the critical path (frame bolded) and with located the time of the cost buffer task

Kolejnym krokiem było ustalenie lokalizacji buforów czasu i kosztu. Zgodnie z przyjętymi założeniami wstawione bufory są wspólne dla czasu i kosztu. Ich lokalizację pokazano na rys. 1 oznaczonych jako sześciokątne ostroboki. W sieci zależności wstawiono dwa bufory wspomagające na ścieżce krytycznej (BWP1 i BWP2), trzy bufory zasilające (BZ1, BZ2, BZ3) oraz bufor projektu $\mathrm{BP}$ będący równocześnie zadaniem kończącym całe przedsięwzięcie. 
Znając lokalizację buforów oraz układ chronionych przez nie ciągów możliwe było wyznaczenie ich parametrów. W pierwszej kolejności skupiono się na skróceniu czasów trwania zadań i wynikających z nich wielkościach buforów czasu. Ze względu na fakt, że wyznaczony wstępnie czas realizacji obiektu wynoszący 264 dni nie mógł być przekroczony, jedyną możliwością wstawienia buforów czasu było odpowiednie skrócenie wyjściowych czasów zadań. Ponieważ dysponowano deterministycznymi ocenami czasu wszystkich zadań (oznaczonych jako $t_{B}$ ), na podstawie oceny eksperckiej, z uwzględnieniem istniejących ograniczeń technologicznych i organizacyjnych, oszacowano najkrótsze możliwe czasy wszystkich zadań (oznaczono je jako $t_{A}$ ). Zgodnie z założeniami Goldratta połowa uzyskanego skrócenie czasu każdego zadania $\Delta t=t_{B}-t_{A}$ została przeniesiona do bufora chroniącego dane zadanie, druga połowa umożliwiła skrócenie całego przedsięwzięcia. Nowe czasy zdań zostały wstawione do harmonogramu w programie MS Project co pozwoliło obliczyć, że możliwie najkrótszy czas realizacji całego harmonogramu wynosi 201 dni (bez buforów czasu), a po wstawieniu buforów czasu 234 dni.

Kolejnym krokiem było wyznaczenie kosztów kontyngencji przypisanych do ustalonych już buforów. W danych wyjściowych ustalone były koszty bezpośrednie wykonania wszystkich zadań $\left(k_{B}\right)$, odpowiadające czasom $t_{B}$ i koszty pośrednie całego projektu $(K P)$. Wynikały one m.in. z kosztów obsługi geodezyjnej i geologicznej, urządzenia i obsługi placu budowy, opłat za zajmowanie terenu, płac personelu kadry kierowniczej, kosztów ubezpieczenia itp. Obliczona łączna stawka dzienna tych opłat wynosiła $4715 \mathrm{zł}$. W celu poprawnego naliczenia kosztów pośrednich w MS Project zdefiniowano materiał „Koszty pośrednie" o jednostkowym koszcie użycia 4715 zł, a następnie przypisano ten zasób do zadania sumarycznego całego harmonogramu jako zużycie dzienne w ilości 1/dzień. Dzięki temu, każdego dnia trwania robót, koszty pośrednie były dodawane automatycznie przez program do kosztów bezpośrednich zaplanowanych zadań, a ich łączna wartość zmieniała się w zależności od czasu trwania całego harmonogramu. Znając najkrótszy czas realizacji wszystkich zadań $t_{A}$, na podstawie oceny eksperckiej wyznaczono dodatkowy koszt $\Delta k_{A}$, jaki należy ponieść za skrócenie czasu zadań od $t_{B}$ do $t_{A}$. Szacując wzrost kosztu $\Delta k_{A}$ każdego zadania brano głównie pod uwagę koszty bezpośrednie zasobów odnawialnych, uznając, że koszty zasobów nieodnawialnych zależą głównie od przyjętych rozwiązań konstrukcyjno-materiałowych, a nie przyjętej organizacji pracy [4]. Wyliczone wzrosty kosztów $\Delta k_{A}$ dla poszczególnych zadań zostały następnie podzielone na dwie części. Połowę (oznaczoną $K Z t A$ ) dodano do kosztów wykonania zadań w czasie $t_{B}$, otrzymując w ten sposób koszt $k_{A}$, przypisany bezpośrednio do wykonania zadań w najkrótszym możliwym czasie $t_{A}$. Łatwo zauważyć, że koszt wykonania zadań w skróconym czasie jest większy od kosztów ich realizacji w czasach bez skróceń (tabela1). Drugą część $\Delta k_{A}$ (oznaczoną KBtA) skumulowano w buforach kosztów chroniących poszczególne zadania. W ten sposób zabezpieczono niezbędne nakłady finansowe na realizację projektu, 
a z drugiej strony zabezpieczono się przed ewentualnym przeszacowaniem wzrostu kosztów spowodowanych skróceniem zadań.

Jednak jak podano $\mathrm{w}$ założeniach proponowanej metody całkowity koszt bufora kosztu wynika z dwóch źródeł. Pierwszy element $(K t B)$, stanowi zabezpieczenie kosztów wykonania zadań w podstawowym czasie bez skracania, czyli w czasie $t_{B}$. W tym wypadku, ze względu na brak danych o rozkładach kosztów oraz dostateczną dokładność obliczeń [5], KtB poszczególnych zadań określono jako $10 \%$ kosztu $k_{B}$. Drugim składnikiem jest opisany powyżej mechanizm zabezpieczenia wynikającego ze wzrostu kosztu związanego ze skróceniem zadań. Ostatecznie całkowity koszt rezerwowych nakładów finansowych $B K_{i}$ zgromadzonych w każdym buforze $i$ wyniósł:

$$
B K_{i}=\sum_{j=1}^{m}\left(K t B_{j}+K B t A_{j}\right)
$$

gdzie: $B K_{i}-$ wielkość bufora kosztów $i$,

$m$ - liczba zadań chronionych buforem $i$,

$K t B_{j}$ - rezerwa kosztu wykonania zadania $j$ w czasie $t_{B}$,

$K B t A_{j}$ - rezerwa kosztu zabezpieczająca wykonanie zadania $j$ w skróconym czasie $t_{A}$.

Zaprojektowane skrócenie zadań w kolejnych rozważanych wariantach nie musi być równe maksymalnemu możliwemu skróceniu $\Delta t$. Może również stanowić tylko jego część. W takim wypadku również koszt skrócenia zadania będzie stanowił tylko fragment kosztu $\Delta k_{A}$. W prezentowanym przykładzie przyjęto, że funkcja opisująca wzrost kosztu skrócenia zadań w zależności od wartości tego skrócenia jest prostoliniowa, co w ogólnym przypadku nie ogranicza zastosowania innego przebiegu tej funkcji. W celu zilustrowania możliwości wykonania obliczeń przy założeniu częściowego skrócenia zadań obliczono wariant, w którym przyjęto skrócenie równe połowie maksymalnego (po zaokrągleniu do pełnych dni roboczych). Czasy tak skróconych zadań oznaczono jako $t_{C}$, a odpowiadające im koszty wykonania zadań po skróceniu $k_{c}$. Dane o czasach i kosztach wszystkich zadań zestawiono w tabeli 1 . Wyniki obliczeń wielkości buforów czasu i kosztu przy skróceniu zadań do czasu $t_{A}$ i $t_{C}$ podano w tabeli 2 . Na rys. 2 przedstawiono krzywe skumulowanych całkowitych kosztów wykonania obiektu w trzech rozważanych wariantach: bez skróceń zadań $\left(t_{B}\right)$ oraz z maksymalnym i częściowym skróceniem $t_{A}$ i $t_{C}$. 
Tabela 1. Czasy i koszty bezpośrednie zadań w przykładowym harmonogramie

Table 1. Tasks time and direct cost in PLN for example schedule

\begin{tabular}{|c|c|c|c|c|c|c|c|c|c|}
\hline Id & Nazwa zadania & $\begin{array}{c}t_{B} \\
{[\mathrm{dni}]}\end{array}$ & $\begin{array}{c}t_{A} \\
{[\mathrm{dni}]}\end{array}$ & $\begin{array}{c}k_{B} \\
{[\mathrm{PLN}]}\end{array}$ & $\begin{array}{c}\Delta k_{A} \\
{[\mathrm{PLN}]}\end{array}$ & $\begin{array}{c}k_{A} \\
{[\mathrm{PLN}]}\end{array}$ & $\begin{array}{c}t_{C} \\
{[\mathrm{dni}]}\end{array}$ & $\begin{array}{c}k_{C} \\
{[\mathrm{PLN}]}\end{array}$ & \begin{tabular}{|c|} 
Bufor \\
chroniący
\end{tabular} \\
\hline 1 & $\begin{array}{l}\text { PRZEBUDOWA } \\
\text { ZBIORNIKA - SUMA }\end{array}$ & 264 & 201 & 8935177 & 1772117 & 9821230 & 248 & 9405062 & \\
\hline 2 & Rob. ziemne - grobla & 42 & 32 & 2245573 & 500913 & 2496029 & 37 & 2370801 & BWP1 \\
\hline 3 & $\begin{array}{l}\text { Rob. ziemne - duży } \\
\text { zbiornik }\end{array}$ & 78 & 60 & 683790 & 164644 & 766112 & 69 & 724951 & BWP1 \\
\hline 4 & System napowietrzania & 54 & 38 & 654167 & 139624 & 723979 & 46 & 689073 & $\mathrm{BZ1}$ \\
\hline 5 & Umocnienie strefy brzeg. & 28 & 21 & 149245 & 29150 & 163820 & 24 & 157573 & BZ2A \\
\hline 6 & $\begin{array}{l}\text { Wymiana rurociągu } \\
\text { doprowadzającego }\end{array}$ & 19 & 15 & 304213 & 49717 & 329071 & 17 & 316642 & BWP1 \\
\hline 7 & $\begin{array}{l}\text { Stopnie nawodne drew- } \\
\text { niano-ziemne }\end{array}$ & 12 & 9 & 14507 & 3142 & 16078 & 10 & 15554 & $\mathrm{BZ} 2 \mathrm{~B}$ \\
\hline 8 & Przewał & 3 & 2 & 92931 & 16865 & 101363 & 2 & 101363 & BZ2B \\
\hline 9 & Wylot wody ze zbiornika & 5 & 3 & 800 & 141 & 870 & 4 & 835 & BWP1 \\
\hline 10 & Studnie przeciwpożarowe & 10 & 7 & 80413 & 17498 & 89162 & 8 & 86245 & BWP1 \\
\hline 11 & Pomost tech. północny & 16 & 12 & 71503 & 12497 & 77751 & 14 & 74627 & BWP1 \\
\hline 12 & Pomosty tech. wschodnie & 25 & 19 & 170643 & 28871 & 185078 & 22 & 177860 & BZ2A \\
\hline 13 & Kładka technologiczna & 45 & 34 & 535044 & 94783 & 582435 & 39 & 560893 & BZ2B \\
\hline 14 & $\begin{array}{l}\text { Pochylnia technol. z } \\
\text { betonu zbrojonego }\end{array}$ & 21 & 16 & 17511 & 3087 & 19054 & 18 & 18437 & BZ1 \\
\hline 15 & \begin{tabular}{|l|} 
Roboty elektryczne - \\
rozprowadzenie kabli
\end{tabular} & 26 & 20 & 150619 & 37181 & 169209 & 23 & 159914 & BWP1 \\
\hline 16 & $\begin{array}{l}\text { Skrzynki SO I SZ i na- } \\
\text { powietrzanie }\end{array}$ & 22 & 16 & 87234 & 14230 & 94349 & 19 & 90791 & BZ2A \\
\hline 17 & Plac technologiczny & 11 & 8 & 283335 & 50615 & 308642 & 9 & 300206 & BZ2B \\
\hline 18 & $\begin{array}{l}\text { Drogi technologiczne z } \\
\text { kostki betonowej }\end{array}$ & 39 & 30 & 2331273 & 425718 & 2544132 & 34 & 2449528 & BWP2 \\
\hline 19 & $\begin{array}{l}\text { Przejścia technol. z kost- } \\
\text { ki betonowej }\end{array}$ & 14 & 10 & 226473 & 44668 & 248807 & 12 & 237640 & BZ3 \\
\hline 20 & $\begin{array}{l}\text { Przejścia technol. o } \\
\text { nawierzchni żwirowej }\end{array}$ & 25 & 19 & 456378 & 69550 & 491153 & 22 & 473765 & BZ3 \\
\hline 21 & Szata roślinna & 16 & 12 & 183789 & 35731 & 201654 & 14 & 192721 & BWP2 \\
\hline 22 & Prace porządkowe & 13 & 10 & 109976 & 18422 & 119187 & 11 & 116116 & $\mathrm{BP}$ \\
\hline 23 & Nasadzenia roślinne & 16 & 12 & 85760 & 15070 & 93295 & 14 & 89527 & BZ3 \\
\hline
\end{tabular}

Tabela 2. Czasy i koszty realizacji przykładowego harmonogramu w analizowanych wariantach

Table 2. Time and contingency cost in PLN for example schedule in the analyzed variants

\begin{tabular}{|c|l|c|c|c|c|c|}
\hline Lp & \multicolumn{1}{|c|}{ Wariant } & $\begin{array}{c}\text { Liczba } \\
\text { dni robo- } \\
\text { czych }\end{array}$ & $\begin{array}{c}\text { Koszty } \\
\text { bezpośrednie } \\
\text { zadań [PLN] }\end{array}$ & $\begin{array}{c}\text { Bufory } \\
\text { kosztów } \\
{[\text { [PLN] }}\end{array}$ & $\begin{array}{c}\text { Koszty } \\
\text { pośrednie } \\
{[\text { PLN] }}\end{array}$ & $\begin{array}{c}\text { Koszt całego } \\
\text { projektu } \\
\text { [PLN] }\end{array}$ \\
\hline 1 & $\begin{array}{l}t_{B} \text { bez buforów czasu i } \\
\text { kosztu }\end{array}$ & 264 & 8935177 & 0 & 1244760 & 10179937 \\
\hline 1 a & $\begin{array}{l}t_{B} \text { bez buforów czasu }+ \\
\text { bufory kosztu }\end{array}$ & 264 & 8935177 & 893515 & 1244760 & 11073452 \\
\hline 2 & $t_{A}$ z buforami czasu i kosztu & 234 & 9821230 & 1779568 & 1103310 & 12704108 \\
\hline 3 & $t_{C}$ z buforami czasu i kosztu & 248 & 9405062 & 1363400 & 1169320 & 11937782 \\
\hline
\end{tabular}




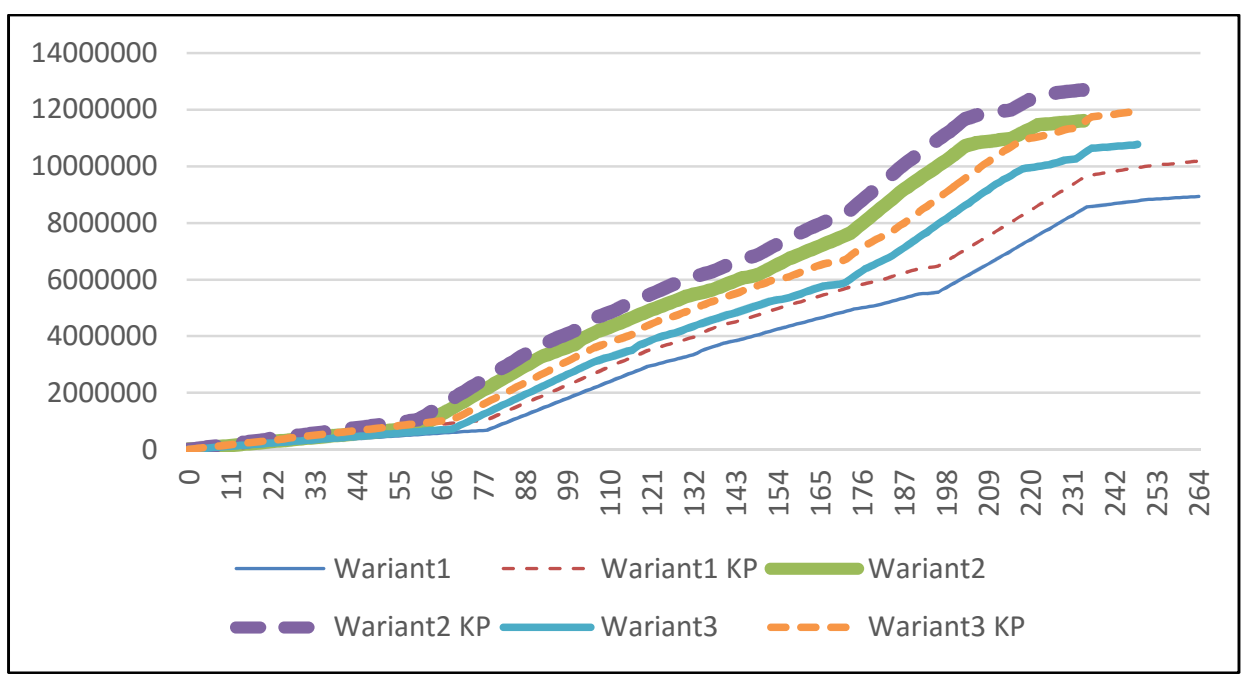

Rys. 2. Skumulowane koszty wykonania obiektu w analizowanych wariantach (z kosztami pośrednimi i bez)

Fig. 2. Summary curves of the budgeted costs in the analyzed variants (direct and indirect cost)

\section{Posumowanie}

Analizując uzyskane wyniki można zauważyć, że koszt realizacji całego obiektu uzależniony jest od terminu zakończenia robót, przy czym im krótszy jest ten termin, tym łączny koszt jest większy. Pierwotnie, przy czasie realizacji 264 dni, koszt wykonania obiektu wynosił 10179937 zł łącznie z kosztami pośrednimi, ale bez żadnych buforów kosztu. Chcąc zabezpieczyć realizację kosztami rezerwowymi (bez skracania czasu przedsięwzięcia) trzeba podnieść koszty o ok. 893 tys zł, co daje kwotę 11073452 zł. Skrócenie okresu realizacji robót do 234 dni podnosi koszty bezpośrednie (z buforami) o ok. 1772 tys zł, ale zmniejsza koszty pośrednie (z 1244760 zł do 1103310 zł), co łącznie daje koszt wykonania obiektu 12704108 zł. Oznacza to, że skrócenie czasu o ok. 11,4\% wymaga wzrostu kosztów o ok. 1631 tys. zł, czyli ok. 14,7\%. Przy czasie realizacji obiektu 248 dni łączny koszt wynosi 11938 tys. zł, co oznacza odpowiednio skrócenie o ok. 6\% i wzrost kosztu obiektu z tytułu łącznych kosztów skrócenia zadań i zmniejszenia kosztów pośrednich o ok. 7,8\%.

Zaproponowana $\mathrm{w}$ artykule metoda wskazuje, w jaki sposób można połączyć wartość kontyngencji kosztów z czasem trwania robót i kontyngencją czasu, określoną w buforach czasu. W artykule nie skupiono się na szczegółowych technikach wyznaczania wielkości buforów czasu i kosztu, a jedynie wskazano na potrzebę i możliwość wzajemnego powiązania tych dwóch ważnych z punktu widzenia analizy ryzyka planowanego przedsięwzięcia parametrów. 


\section{Literatura}

[1] Baccarini D.: Estimating project cost contingency - a model and exploration of research questions, in Khosrowshahi, Farzad (ed), ARCOM 20th Annual Conference, September (2004), pp. 105-113. Heriot-Watt University, Edinburgh: Association of Researchers in Construction Management.

[2] Goldratt E.: Łańcuch krytyczny. Wyd. WERBEL, Warszawa, 2000.

[3] Kasprowicz T.: Kontyngencja przedsięwzięć budowlanych. Biuletyn Wojskowej Akademii Technicznej, Vol. 53, nr 8, 2004, s. 91-108.

[4] Marcinkowski R.: Harmonogramowanie w produkcji budowlanej, Studia z zakresu inżynierii nr 57, s. 79-118, KILiW PAN, Warszawa 2007.

[5] Połoński M.: Budżetowanie przedsięwzięć budowlanych z uwzględnieniem buforów czasu i kosztu, Budownictwo i Architektura, 13(4), 2014, s. 389-398.

[6] Połoński M., Pruszyński K.: Lokalizacja buforów czasu w metodzie łańcucha krytycznego w harmonogramach robót budowlanych (cz. I) - podstawy teoretyczne, Przegląd Budowlany, No. 2, 2008, 45-49.

[7] Rosińska A.: Projekt technologiczno - organizacyjny wykonania zbiornika retencyjnego w Małomicach z elementami ryzyka czasu i kosztu, praca magisterska,. SGGW, 2014.

[8] Steyn H.: An investigation into the fundamentals of critical chain project scheduling, International Journal of Project Management, Vol. 19, 2000, pp. 363-369.

\section{RELATIONSHIP BETWEEN TIME CONTINGENCY AND COST CONTINGENCY IN CONSTRUCTION SCHEDULES}

\section{S u m m a r y}

Considering time and/or cost buffers in the structures of CPM schedules is becoming a more and more popular method of protecting construction schedules against numerous risk factors occurring during object accomplishment. So far, solutions offered by published reports usually allow for determining their magnitude independently from each other. This means that the cost buffers do not include the costs required for shortening of tasks, which are the basic assumption of the Goldratt method. The paper shows that the cost contingency amassed in the buffers should depend on the shortening dimensions of tasks protected by a given buffer. The assumptions of the proposed method for determining the magnitude of cost buffers depending on the assumed completion time of the object accomplishment and the resulting time shortenings for the tasks are presented and discussed, and the calculation procedure is described. The proposed method of buffer determination is illustrated and verified based on a large schedule of a water reservoir reconstruction.

Keywords: time contingency, cost contingency, risk analysis, time buffers, cost buffers, construction schedule

Przestano do redakcji: 07.06.2016 $r$.

Przyjęto do druku: 30.06 .2016 r.

DOI: $10.7862 / \mathrm{rb} .2016 .23$ 